\title{
Doğu Karadeniz Bölgesi'ndeki Gebe Kadınlarda Rubella Virus Seroprevalansı
}

\section{Seroprevalence of Rubella Virus among Pregnant Women in Eastern Black Sea Region}

\author{
Şenol Şentürk ${ }^{1, *}$, Mehmet Kağıtcı ${ }^{1}$, Gülşah Balık ${ }^{1}, K_{\text {azım Şahin }}{ }^{2}$, Figen Kır Şahin $^{1}$ \\ ${ }^{1}$ Recep Tayyip Erdoğan Üniversitesi T⿰力 Fakültesi, Kadın Hastalıklar ve Doğum Anabilim Dalı, Riže, Türkiye \\ ${ }^{2}$ Recep Tayyip Erdoğan University, Tıbbi Mikrobiyoloji Anabilim Dalı, Rize, Türkiye
}

\begin{abstract}
ÖZET
Amaç: Rubella virus Togaviridae familyasının Rubivirus genusunun tek üyesidir. Zarflıdır ve tek sarmallı ribo nükleik asit genomuna sahiptir. Bu viruse ilk trimesterde maruz kalan annelerin doğmamış çocukları konjenital rubella sendromu açısından yüksek risk altındadırlar. Bu çalışmada hastanemiz gebe polikliniklerine başvuran gebelerde rubella antikorlarının sıklığının tespit edilmesi amaçland1.
\end{abstract}

Gereç ve Yöntem: Bu çalışmada hastanemiz gebe polikliniğine 31.07.2009 ile 01.08.2014 tarihleri arasında başvuran 1037 gebenin rubella $\operatorname{IgM}$ ve 424 gebenin rubella $\operatorname{IgG}$ antikor değerleri retrospektif olarak incelendi.

Bulgular: Rubella IgG ölçümüne göre olguların $\% 1,9$ 'unun $(\mathrm{n}=8)$ rubella $\operatorname{IgG}$ sonucu negatif, \%4,2'sinin $(n=18)$ ara değer ve \%93,9'unun $(n=398)$ rubella $\operatorname{IgG}$ sonucu pozitif olarak saptand. Rubella IgM ölçümüne göre olguların \%99,2'sinin ( $\mathrm{n}=1029)$ rubella IgM sonucu negatif, $\% 0,5$ 'inin $(n=5)$ ara değer ve $\% 0,3$ 'ünün $(n=3)$ rubella IgM sonucu pozitif olarak saptand.

Sonuç: $\mathrm{Bu}$ çalıșma ile yöremizdeki gebe kadınlarda 5 yıllık dönemde rubella virüs seroprevalansı tespit edildi. Bölgemizde rubella $\operatorname{IgG}$ seroprevalansı oldukça yüksektir ve bu sebeple gebelerde rutin olarak taranmasinin gerekli olmadığını düşünüyoruz. Rubella IgM seropozitivitesi ise oldukça düşüktür ve bu sebeple de bu bölgede rutin rubella IgM taraması yapmadan önce obstetrisyenlerin maliyet etkinlik açısından değerlendirme yapmaları gerekir.

Anahtar kelimeler: Rubella, seroprevalans, gebelik

\section{Giriş}

Rubella virus Togaviridae familyasının Rubivirus genusunun tek üyesi olan zarflı ve tek sarmallı

\begin{abstract}
Objective: Rubella virus, a member of the Togaviridae family is the sole member of the genus Rubivirus. It is enveloped and has a single stranded ribonucleicacid genome. Infection acquired in the first trimester of pregnancy poses high risk of congenital rubella syndrome to the unborn child. In the present study we aimed to investigate seroprevalance of rubella antibodies among pregnant women who were admitted to our obstetrics department.
\end{abstract}

Materials and Methods: In this retrospective study, 1037 pregnant women were investigated for rubella $\mathrm{IgM}$ antibody and 424 for rubella $\operatorname{IgG}$ antibody, who were admitted to our obstetric clinic between 31st July 2009 and $1^{\text {st }}$ August 2014.

Results: Rubella IgG results of the patients were; $1,9 \%$ $(n=8)$ negative, 4,2\% ( $n=18)$ grayzone and $93,9 \%$ $(n=398)$ positive. Rubella IgM results of the patiences were; $99,2 \%(n=1029)$ negative, $0,5 \%(n=5)$ grayzone and $0,3 \%(\mathrm{n}=3)$ positive.

Conclusion: As a result, in this study we identified the last 5 years seroprevalance of rubella virus in our region. Seropositivity of rubella virus is high in our region and we think routine screening for rubella $\mathrm{IgG}$ is not necessary. Seropositivity rubella IgM is very low in our region. Therefore, obstetricians should reconsider the cost-effectiveness of routine screening for rubella IgM.

Key Words: Rubella, seroprevalence, pregnancy

ribonükleik asit taşıyan bir virüstür (1). Virus solunum yoluyla bulaşır ve nazofarinkste replike olduktan sonra servikal lenf nodlarında çoğalmaya devam eder. Kan dolaşımına karışan virus bu yolla vücuda yayilır.

*Sorumlu Yazar: Dr. Şenol Şentürk, Recep Tayyip Erdoğan Üniversitesi, Tıp Fakültesi Dekanlı̆̆1, Kadın Hastalıkları ve Doğum Anabilim Dalı, Tıp Fakültesi Dekanlığı, İslampaşa Mahallesi, No.74, 53000 Rize/Türkiye

Tel: 0 (464) 21703 70, Fax: 0 (464) 2170364

E-mail:dr.senturk@hotmail.com

Geliş Tarihi: 05.02.2015, Kabul Tarihi: 14.04.2016 
Rubella sıklıkla aynı gün başlayan halsizlik, subfebril ateş ve döküntülerle ortaya çıar. Döküntüler yüzde başlar, gövdeye doğru yayılır ve nadiren 3 günden uzun sürer (2). Gebelik esnasında rubella virusu infeksiyonuyla karşılaşan annelerin bebekleri doğduklarında konjenital rubella sendromu (KRS) ile doğabilirler. İlk trimesterde karşılaşılması durumunda ise bu risk daha yüksektir. Konjenital rubella infeksiyonu tüm organ sistemlerini etkileyebilir ancak en yaygın ve sıklıkla ortaya çıkan morbidite sağırlıktır. Katarakt, glokom, retinopati ve mikroftalmi gibi göz hastalıkları da ortaya çıkabilir $(3,4)$.

Rubella infeksiyonunun kesin tanısı için ya virüsün izolasyonu ya da virüse özgül antikorların serolojik testlerle tespit edilmesi gerekmektedir. Bu amaçla ELISA, rubella $\operatorname{IgM}$ ve $\operatorname{IgG}$ antikorlarının tespitinde yaygin olarak kullanılmaktadır (5). Rubella IgG antikorları geçirilmiş infeksiyonu gösterirken rubella $\operatorname{IgM}$ antikorlar1, primer veya rekürren rubella infeksiyonu göstergesi kabul edilir ve aktif infeksiyonun varllğına işaret etmektedir (5).

Rize ili ve ilçelerini kapsayan bölgemizde, konjenital infeksiyona ve sonuçta fetal malformasyonlara neden olabilen rubella infeksiyonu seroprevalansı hakkında yeterli veri bulunmamaktadır. $\mathrm{Bu}$ çalışmada hastanemiz gebe polikliniklerine başvuran gebe kadınlardan rutin taramalar kapsamında istenen serum örneklerinde rubella antikorlarının sıklı̆g ve yaş gruplarına göre dağılımının tespit edilmesi amaçlandı.

\section{Gereç ve Yöntem}

$\mathrm{Bu}$ çalışmada hastanemiz gebe polikliniğine 31.07.2009 ile 01.08.2014 tarihleri arasında başvuran 1037 gebenin rubella $\mathrm{IgM}$ ve rubella $\mathrm{IgG}$ antikor değerleri retrospektif olarak incelendi. Gebelerin 1037'sinde rubella IgM, 424 gebede ise aynı anda rubella IgG antikor değerleri bakıldığ1 tespit edildi. Hastalar yaş olarak 25 ve alt1, 26-35 aras1, 36 ve üzeri olarak 3 gruba ayrıldı. Hastaların antikor değerleri, hastanemizin Mikrobiyoloji ve Klinik Mikrobiyoloji Seroloji Laboratuvarnnda Abbott firmasının Architect Rubella-IgG ve IgM ticari kitleri kullanılarak saptandı. Polikliniklere rutin gebelik takibi için başvuran kadınlardan alınan kan örneklerinden santrifüj sonrası ayrılan serumlar bekletilmeden aynı gün içerisinde kemilüminesan mikropartikül immünoassay (CMIA) yöntemi (Architect, ABBOTT, USA) ile çalışıldı. Sonuçlar değerlendirilirken kitin değerlendirme kriterlerine uygun olarak anti-rubella $\operatorname{IgG}$ için $<5.0$ değerler negatif, 5.0 -10.0 arası değerler ara değer, $>=$ 10.0 değerler pozitif olarak kabul edildi. Anti-rubella IgM için <1.2 değerler negatif, 1.2 - 1.6 arası değerler ara değer, $>=1.6$ değerler ise pozitif olarak kabul edildi. İstatistiksel analizler için NCSS
(NumberCruncher Statistical System) 2007\&PASS (Power Analysis and Sample Size) 2008 Statistical Software (Utah, USA) programı kullanıldı. Çalışma verileri değerlendirilirken tanımlayıc1 istatistiksel metodlarin (Ortalama, Standart Sapma, Medyan, Frekans, Oran, Minimum, Maksimum) yanısıra normal dağllım göstermeyen rubella $\operatorname{IgG}$ ve $\operatorname{IgM}$ ölçümlerinin yaş gruplarına göre değerlendirmelerinde, Kruskal Wallis Test ve farklillğa neden çıan grubun tespitinde Mann Whitney U Test kullanıld. Anlamlılık $\mathrm{p}<0,01$ ve $\mathrm{p}<0,05$ düzeylerinde değerlendirildi.

\section{Bulgular}

Çalışma rubella $\operatorname{IgG}$ bakılan 424 olgu ve rubella IgM bakılan 1037 olgu üzerinde yap1ld1. Rubella IgG antikoru bakılan olguların yaşları 18 ile 48 yıl arasında değişmekte olup, ortalama 31,23 $\pm 5,72$ y1l olarak saptand. Rubella IgG ölçümüne göre olgularin \%1,9'unun $(\mathrm{n}=8)$ rubella $\operatorname{IgG}$ sonucu negatif, \%4,2'sinin $(\mathrm{n}=18)$ ara değer ve $\% 93,9$ 'unun $(\mathrm{n}=398)$ rubella $\operatorname{IgG}$ sonucu pozitif olarak saptandi. Olguların \%17'si $(\mathrm{n}=72) 25$ yaş ve altında gözlenirken, \%61,3'ü $(n=260) 26$ ile 35 yaş arasında ve \%21,7'si $(n=92) 36$ yaş ve üzerinde gözlendi. Yaş gruplarına göre olguların rubella IgG ölçümleri arasında istatistiksel olarak ileri düzeyde anlamlı farklılık saptand1 (Kruskal Wallis testi, $\mathrm{p}=0,001 ; \mathrm{p}<0,01) . \quad$ Farklılığ1 belirlemek amacıyla yapılan Mann Whitney ikili karşılaştırma testi sonuçlarına göre; yaşı 25 ve altı olan olguların rubella $\operatorname{IgG}$ ölçümü, yaş1 26 ile 35 yil arasında olan ve yaş1 36 ve üzeri olgulara göre anlamlı düzeyde yüksek olarak bulundu ( $\mathrm{p}=0,008 ; \mathrm{p}=0,001$; $\mathrm{p}<0,01)$. Yaşı 26 ile 35 y1l aras1 olan olguların rubella IgG ölçümü, yaşı 36 ve üzeri olan olgulara göre anlamlı düzeyde yüksek olarak tespit edildi $(\mathrm{p}=0,001 ; \mathrm{p}<0,01)$ (Tablo 1).

Rubella IgM antikoru bakılan olguların yaşları 15 ile 49 yil arasında değişmekte olup, ortalama $30,28 \pm 5,92$ y1l olarak saptand. Olgularin \%21,8'i $(\mathrm{n}=226) 25$ yaş ve altında gözlenirken, \%60,3’ü $(n=625) 26$ ile 35 yaş arasında ve \%17,9'u $(n=185)$ 36 yaş ve üzerinde gözlendi. Rubella $\operatorname{IgM}$ ölçümüne göre olguların \%99,2'sinin $(n=1029)$ rubella $\operatorname{IgM}$ sonucu negatif, $\% 0,5$ 'inin $(n=5)$ ara değer ve $\% 0,3$ 'ünün $(n=3)$ rubella $\operatorname{IgM}$ sonucu pozitif olarak saptandi. Yaş gruplarına göre olguların, rubella IgM ölçümleri arasında istatistiksel olarak ileri düzeyde anlamlı farklılık saptand 1 (Kruskal Wallis testi, $\mathrm{p}=0,001 ; \mathrm{p}<0,01$ ). Farklılığ1 belirlemek amaciyla yapılan Mann Whitney ikili karşılaştırma testi sonuçlarına göre; yaşı 25 ve altı olan olguların rubella IgM ölçümü, 
Tablo 1. Rubella IgG sonuçları mevcut olan olguların dağıllımları

\begin{tabular}{|c|c|c|c|c|}
\hline & & & Min - Max & Ort $\pm S D$ \\
\hline \multirow{3}{*}{\multicolumn{2}{|c|}{$\begin{array}{l}\text { Yaş (Yil) } \\
\text { Rubella IgG }\end{array}$}} & & $18-48$ & $31,23 \pm 5,72$ \\
\hline & & & $0,00-500,00$ & $117,28 \pm 125,90$ \\
\hline & & & $\mathrm{n}$ & $\%$ \\
\hline \multirow{3}{*}{\multicolumn{2}{|c|}{ Yaş grup }} & $\leq 25$ & 72 & 17,0 \\
\hline & & $26-35$ & 260 & 61,3 \\
\hline & & $\geq 36$ & 92 & 21,7 \\
\hline \multirow{4}{*}{\multicolumn{2}{|c|}{$\begin{array}{l}\text { Rubella IgG'e } \\
\text { göre sonuç }\end{array}$}} & Negatif & 8 & 1,9 \\
\hline & & Ara değer & 18 & 4,2 \\
\hline & & Pozitif & 398 & 93,9 \\
\hline & & $\leq 25$ Yaş & $26-35$ Yaş & $\geq 36$ Yaş \\
\hline \multirow{3}{*}{$\begin{array}{l}\text { Rubella } \\
\text { IgG } \\
\text { sonucu }\end{array}$} & Negatif; $n(\%)$ & $0(\% 0,0)$ & $7(\% 2,7)$ & $1(\% 1,1)$ \\
\hline & Ara değer; $n(\%)$ & $1(\% 1,4)$ & $9(\% 3,5)$ & $8(\% 8,7)$ \\
\hline & Pozitif; $n(\%)$ & $71(\% 98,6)$ & $244(\% 93,8)$ & $83(\% 90,2)$ \\
\hline \multicolumn{2}{|c|}{$\begin{array}{l}\text { Rubella IgG sonucu Ort } \pm S D \\
\text { (Medyan) }\end{array}$} & $161,71 \pm 141,25(122,55)$ & $117,82 \pm 125,42(72,70)$ & $81,00 \pm 125,90(69,05)$ \\
\hline
\end{tabular}

Kurskall Walis Test

Tablo 2. Rubella IgM sonuçları mevcut olan olguların dağılımları

\begin{tabular}{|c|c|c|c|c|}
\hline & & Min - Max & \multicolumn{2}{|l|}{ Ort $\pm S D$} \\
\hline Yaş (Yil) & & $15-49$ & $30,28 \pm 5,92$ & \\
\hline \multirow[t]{2}{*}{ Rubella IgM } & & $0,04-7,56$ & $0,26 \pm 0,30$ & \\
\hline & & $\mathrm{n}$ & $\%$ & \\
\hline \multirow{3}{*}{ Yaş grup } & $\leq 25$ & 226 & 21,8 & \\
\hline & $26-35$ & 625 & 60,3 & \\
\hline & $\geq 36$ & 185 & 17,9 & \\
\hline \multirow{3}{*}{$\begin{array}{l}\text { Rubella IgM’e göre } \\
\text { sonuç }\end{array}$} & Negatif & 1029 & 99,2 & \\
\hline & Ara değer & 5 & 0,5 & \\
\hline & Pozitif & 3 & 0,3 & \\
\hline & & $\leq 25$ Yaş & $26-35$ Yaş & $\geq 36$ Yaş \\
\hline \multirow{3}{*}{ Rubella IgM sonucu } & Negatif; $n(\%)$ & $225(\% 99,6)$ & $618(\% 98,9)$ & $185(\% 100,0)$ \\
\hline & Ara değer; $n(\%)$ & $0(\% 0,0)$ & $5(\% 0,8)$ & $0(\% 0,0)$ \\
\hline & Pozitif; $n(\%)$ & $1(\% 0,4)$ & $2(\% 0,3)$ & $0(\% 0,0)$ \\
\hline \multicolumn{2}{|c|}{ Rubella IgM sonucu Ort $\pm S D$ (Medyan) } & $0,29 \pm 0,18(0,26)$ & $0,27 \pm 0,36(0,20)$ & $0,21 \pm 0,11(0,19)$ \\
\hline
\end{tabular}

Kruskal Wallis Test

yaşı 26 ile 35 yıl arasında olan ve yaşı 36 ve üzeri olgulara göre anlamlı düzeyde yüksek olarak tespit edildi ( $p=0,001 ; p=0,001 ; p<0,01)$. Yaş1 26 ile 35 y1l arası olan olguların rubella IgM ölçümü, yaşı 36 ve üzeri olan olgulara göre anlamlı düzeyde yüksek olarak saptand $1(\mathrm{p}=0,037 ; \mathrm{p}<0,05)($ Tablo 2$)$.

\section{Tartışma}

Rubella teratojenik bir virustür ve KRS ciddi malformasyonlara sebep olabilecek bir durumdur
(6). Gebeliğin erken dönemlerinde rubella ile karşılaş1lırsa bu virusün fetuse geçme olasıllı̣̆ $\% 90$ 'dir. Bu durumda fetus intrauterin olarak ölebilir veya KRS ortaya çıkabilir (7). Aşıyla önlenebilir bir hastalık olmasına rağmen kızamıkçık halen tüm dünyada tahminen günde 450 ölüme neden olmaktadır (8).

Rubella aşısının bulunmasından önce kızamıkçık infeksiyonunun endemik olduğu dönemlerde her 1000 canlı doğumda KRS insidans1 0.1-0.2 oranında epidemik olduğu dönemlerde ise $0.8-4$ 
oranında olduğu tespit edilmiştir. Geçtiğimiz dönemlerde uygulanan rubella aşılamaları sonrasında ise pek çok gelişmiş ve gelişmekte olan ülkelerde pratikte bu enfeksiyon ve KRS elimine edilebilmiştir (7). Dünya sağllk örgütü (DSÖ), çocukluk çağı aşılama programları ve kampanyalarında kızamık-kızamıkçık veya kızamık-kabakulak-kızamıkçık aşılarının bir arada yapilarak rubella infeksiyonuyla mücadele edilmesini önermektedir (9). Gebe kadınlar sıklıkla rubella immunitesi açısından taranmaktadır, ancak üreme çağındaki kadınların özellikle gebelikten önceki dönemde virüse duyarlı olmaları konjenital infeksiyon ve sekelleri açısından risk oluşturmaktadır (10).

Gebelerde fetal anomali oluşturan intrauterin infeksiyonlarin prenatal olarak serolojik tarama yapılmasının gerekli olup olmadı̆̆ tartışmalı bir konudur (11). Bir bölgede bu konjenital infeksiyonlara yol açan etkenlerin rutin tarama yapılmasının gerekliliğini saptamada o bölgeye ait seropozitiflik oranlarının bilinmesi önemlidir. $\mathrm{Bu}$ amaçla yaptığımız çalışmada, gebe kadınlarda rubella $\operatorname{IgG}$ yönünden seropozitiflik oran1 \%93.9 olarak saptand1.

Konjenital rubellanın toplumdaki oran1; kişilerin duyarlılığına, etkenin toplumdaki sirkülasyonuna ve aşı kullanımına göre değişmektedir. Türkiye genelinde doğurganlık yaşındaki kadınlarda antirubella $\operatorname{IgG}$ seropozitifliği \%82-93.5, anti-rubella IgM pozitifliği ise \%0-1.9 olarak gözlenmektedir (12-14). Yurt dişında çeşitli ülkelerde yapılan çalışmalarda, rubella seropozitifliği doğurganlık yaşındaki kadınlarda \%70-99 olarak bildirilmektedir (15). Bizim çalışmamızda, gebe kadınlarda anti-rubella IgM pozitifliği \%0.30, antirubella $\operatorname{IgG}$ pozitifliği \%93.9 oranında tespit edildi. Tespit edilen anti-rubella antikor pozitiflik oranları literatürle uyumlu olarak bulundu.

Doğurganlık çağındaki kadınlarda rubella seropozitifliğini araştıran çeşitli çalışmalar ülkemiz dışında da yapılmaktadır. İtalya'da rubella seropozitifliği \%90 (16), Avustralya'da \%99 (17), Arabistan'da \%70 (18), Nijerya'da \%87.5 (10) olarak bulunmuştur. Yurdumuzda hamilelerde yurdumuzun çeşitli bölgelerinde yapılan çalışmalarda Denizli'de anti-rubella IgG pozitifliği \%95.1 anti-rubella IgM pozitifliği \%0 (19), Van'da anti-rubella $\operatorname{IgG}$ pozitifliği $\% 99.5$ IgM pozitifliği $\% 0.3$ (11), Ankara'da anti-rubella IgG pozitifliği $\% 86.5$ IgM pozitifliği \%3.2 (20), Uşak'da antirubella IgG pozitifliği \%92.2 IgM pozitifliği $\% 1.0$ (21), İzmir'de anti-rubella IgG pozitifliği \%95.9 (22), Mardin'de doğurganlık çağındaki kadınlarda anti-rubella $\operatorname{IgG}$ pozitifliği \%76.5 IgM pozitifliği
$\% 0.95$ (23), Malatya'da anti-rubella $\operatorname{IgG}$ pozitifliği $\% 88$ IgM pozitifliği \%0.3 (24) olarak gösterilmiştir.

Genellikle çalışmalar, rubella seopozitifliği açısından yaş grupları arasında fark olduğunu ve yaş arttıkça pozitiflik oranının da arttığını göstermektedir $(5,22)$. Çalışmamızda yaş gruplarına göre olguların rubella IgG ve IgM ölçümleri arasında istatistiksel olarak ileri düzeyde anlamlı farklılık saptanmış ve yaş arttıkça pozitiflik oranının azaldığını göstermektedir (Kruskal Wallis testi, $\mathrm{p}=0,001 ; \mathrm{p}<0,01) . \quad$ Rubella $\operatorname{IgG}$ pozitifliğinin erken yaşlarda daha yüksek bulunmasını aşılama programının başarılı olmasına bağlıyoruz.

Sonuç olarak; bu çalsşma ile yöremizdeki gebe kadınlarda 5 yıllık dönemde rubella virüs seroprevalans1 tespit edildi. Daha önceki y1llarda yöremize ait benzer veriler olmadığından literatüre katk1 verdiğimizi düşünmekteyiz. Yapılan bu çalışma ile bölgemizdeki gebelerde tespit edilen yüksek rubella $\operatorname{IgG}$ seropozitiflik oranları göz önüne alındığında rubella IgG için tarama stratejik açıdan gerekli değilmiş gibi görünmektedir. Rubella IgM seropozitivitesi ise oldukça düşük bulunması nedeniyle bu bölgede rutin rubella $\operatorname{IgM}$ taramas1 yapmadan önce obstetrisyenlerin maliyet etkinlik açısından değerlendirme yapmaları gerekmektedir.

\section{Kaynaklar}

1. Frey TK. Molecular biology of Rubella virus. Adv Virus Res 1994; 44: 69-160.

2. Brooks GF, Caroll KC, Butel JS, Morse SA. 24th ed. USA: McGraw-Hill Companies Inc; 2007. Jawetz, Melnick and Adelbergs Medical Microbiology; pp. 562-565.

3. Lee JY, Bowden DS. Rubella virus replication and links to teratogenicity. Clinical Microbiology Reviews 2000; 13(4): 517-587.

4. Givens KT, Lee DA, Jones T, Ilstrup DM. Congenital rubella syndrome: ophthalmic manifestations and associated systemic disorders. Br J Ophthalmol 1993; 77(6): 358-363.

5. Truant AL, Barksdale BL, Huber TW, Elliott LB. Comparison of an enzyme-linked immunosorbent assay with indirect hemagglutination and hemagglutination inhibition for determination of rubella virus antibody: evaluation of immune status with commercial reagents in a clinical laboratory. J Clin Microbiol 1983; 17(1): 106-108.

6. Rasmussen SA. Human teratogens update 2011: Can we ensure safety during pregnancy? Birth Defects Res A Clin Mol Teratol 2012; 94(3): 123-128.

7. Rubella vaccines: WHO position paper. Wkly Epidemiol Rec 2011; 86(29): 301-316.

8. Esteghamati A, Gouya MM, Zahraei SM, Dadras MN, Rashidi A, Mahoney F. Progress in measles and 
rubella elimination in Iran. Pediatr Infect Dis J 2007; 26(12): 1137-1141.

9. Hamkar R, Jalilvand S, Mokhtari-Azad T, Jelyani KN, Nategh R. Evaluation of immunity against rubella in Iranian after mass campaign for measles-rubella vaccination on December 2003. Am J Infect Control 2006; 34(9): 588-592.

10. Kolawole OM, Anjorin EO, Adekanle DA, Kolawole CF, Durowade KA. Seroprevalence of rubella IgG antibody in pregnant women in osogbo, Nigeria. Int J Prev Med 2014; 5(3): 287-292.

11. Efe Ş, Kurdoğlu Z, Korkmaz G. Van Yöresindeki Gebelerde Sitomegalovirüs, Rubella ve Toksoplazma Antikorlarının Seroprevalansı. Van Tip Dergisi 2009; 16(1): 6-9.

12. Guner H, Gunay A, Rota S. Seroprevalence of rubella virus in Turkish pregnant women. Int J Gynaecol Obstet 1994; 44(2): 139-141.

13. Akyar I. Seroprevalence and Coinfections of Toxoplasma gondii in Childbearing Age Women in Turkey. Iran J Public Health 2011; 40(1): 63-67.

14. Doğan N, Akgün Y. Düşük, ölü doğum, erken doğum öykülü doğurganlık yaş grubu hastalarda TORCH etkenlerinin dağılımı. Türkiye Parazitoloji Derg 1996; 20(3): 317-323.

15. Montoya JG, Kovacs JA, Remington JS. Toxoplasma gondii. In: Mandell GL, Bennett JE, Dolin R, eds. Principles and Practice of Infectious Diseases. 6th ed. Philadelphia: Elsevier Churchill Livingstone 2005: 3170-3198.

16. Canessa A, Pantarotto F, Miletich F, Russo A, Gotta C, Bozzuffi PM, et al. Antibody prevalence to torch agents in pregnant women and relative risk of congenital infections in Italy (Liguria). Biol Res Pregnancy Perinatol 1987; 8(2 2D Half): 84-88.
17. Skurel IJ, Head JL, Garland SM. Detection of rubella spesific immunoglobulin G. J Clin Microbiol 1991; 29(8): 1752-1753.

18. Massoud M, el Tagui M, Saleh W. Specific rubella virus $\operatorname{IgG}$ and $\operatorname{IgM}$ in umbilical cord sera in Saudi Arabia. J Egypt Public Health Assoc 1991; 66(3-4): 387-95.

19. Karabulut A, Polat Y, Türk M, Balc1 YA. Evaluation of rubella, Toxoplasma gondii, and cytomegalovirus seroprevalences among pregnant women in Denizli province. Turk J Med Sci 2011; 41(1): 159-164.

20. Cengiz A, Cengiz L, Us E, Cengiz T. Gebe kadınların serumlarında rubella $\operatorname{IgG}$ ve IgM'nin elisa ile araştırılması. İnfeksiyon Dergisi (Turkish Journal of Infection) 2005; 19(1):19-24.

21. Toklu GD. Antibodies Frequency Against Toxoplasmosis, Rubella Virus and Cytomegalovirus in Pregnant Women Gebelerde Toksoplazma, Rubella Virus ve Sitomegalovirus'a Karșı Olușan Antikorların Sıklığı. J Clin Anal Med 2013; 4(1): 3840.

22. Akınc1 P, Altuğlu İ, Sertöz R, Zeytinoğlu A. İzmir'deki gebelerde Rubella ve Sitomegalovirüs infeksiyonu seroprevalansı. İnfeksiyon Dergisi 2007; 21: 183-186.

23. Tekin A, Deveci Ö, Yula E. Mardin'de doğurganlık çağındaki kadınlarda toksoplazma ve rubella antikor seroprevalans1. J Clin Exp Invest 2010; 1(2): 81-85.

24. Tekerekoğlu MS, Çizmeci Z, Özerol İH, Durmaz R. Doğurganlık Çağındaki Kadınlarda Rubella ve Sitomegalovirus Antikorlarının Araştırılması. İnönü Üniversitesi Tip Fakültesi Dergisi 2003; 10(3): 129131. 